27. Reuss.-Wiener med. Wochenschr., Nr. 19, 1908.

28. Richter.-Klin. Monatsbl.f. Augenheilk., Vol. LXXV, p. 475, 1925.

29. Schaeffer Parsons.-Anat. Record, 1924, ref. Zentralbl. f. Ophthal., Vol. XV, p. 78, 1925.

30. Schöninger.-Klin. Monatsbl. f. Augenheilk., Vol. LXXII, p. 526, 1925.

31. de Schweinitz. - Trans. Ophthal. Soc., U.K., Vol. XLIII, p. 12, 1923.

32. Stargardt and Schall.--Monatschr. f. Geburtsh. u. Gynäk., p. 75, 1925.

33. Wickel. - Ref. v. Hippel.

34. Zander.-Deutsch. med. Wochenschr., 1897.

\title{
ANNOTATIONS
}

\section{The present arrangements regarding Ophthalmic Benefits under the Insurance Acts}

Readers of this journal will probably remember that as the outcome of a conference held at the house of the Royal Society of Medicine in May, 1924, between representatives of the Council of British Ophthalmologists and of the British Medical Association, a joint committee was appointed to consider the administration of "optical benefits" under the National Insurance Act. This committee drew up a series of recommendations which are published in Vol. VIII, page 590 of this journal. These recommendations after receiving the approval of the Council of British Ophthalmologists, the British Medical Association, and the Ophthalmic Benefits Committee, were forwarded to the Ministry of Health with which prolonged negotiations ensued, the result being that the term "optical benefit" has been altered to "ophthalmic benefit." According to a communication addressed to the British Medical Association by the Ministry on October 8, 1926, the normal procedure for the administration of this "ophthalmic benefit" is now as follows :

"An insurance practitioner is required, if the condition of one of his patients is such as to require ophthalmic treatment not within the scope of his agreement with the Insurance Committee, to furnish the patient with a signed written recommendation that such treatment should be obtained. The patient then hands the recommendation to his approved society and applies for ophthalmic benefit, which request, if granted by the society, can only result in the patient being instructed to consult any one of the practitioners upon the Association's list of ophthalmic surgeons who have expressed their willingness to treat insured persons at the fee of one guinea. At the same time the society must furnish the patient with some written authority for production to the ophthalmologist at the outset of the consultation which shows that the 
society undertakes to defray the ophthalmologist's fee of one guinea."

Though the above arrangements are good so far as they go they do not provide satisfactory ophthalmic treatment for all insured patients who require it. The "ophthalmic benefit" is not yet a "standard benefit" available to all insured persons throughout the country; only those are entitled to receive it who are nembers of approved societies having surplus funds, which agree to give the benefit, after having received the sanction of the Ministry of Health. Even then the member must have been attached to the society the whole of the time whilst the surplus has been accumulating.

It has already become apparent that some of the societies which have adopted the benefit are not administering it strictly in accordance with the intentions of the Ministry of Health. Some of the officials protest that their societies are unable to pay an ophthalmic surgeon's fee in all cases and adopt the dangerous practice of sending some of their members direct to opticians. Such societies naturally find a difficulty in deciding which cases to send to ophthalmic surgeons and which to opticians, and forms have been issued by them in which the insurance practitioner is invited to make this decision, a responsibility which, if wise, he will seldom undertake.

Obviously, the whole matter of the administration of ophthalmic benefits still requires vigilance and careful consideration. It is very desirable that the joint committee of the Council of British Ophthalmologists and the British Medical Association, which has already accomplished so much, should be resuscitated to carry on still further its useful work.

\section{The Welfare of the Blind}

Ophthalmology is primarily concerned with the prevention and not with the treatment of blindness. Unfortunately our efforts are not always crowned with success, hence the care of the blind becomes a subject of interest to all of us. The great war, by adding numbers of intelligent and, apart from their blindness, sound young adults to the ranks of the blind, brought about considerable improvements in the methods of educating them, not only to be self-supporting, but also to share in many enjoyments previously denied to them. Amongst the latter, Braille, as applied to literature and music, takes the first place.

The most important Braille library is that of the National Library for the Blind, with headquarters in London and a Northern branch in Manchester. The library was founded in 1882 by a 